\title{
Jean Starobinski medical historian
}

\author{
By Erwin H. Ackerknecht
}

It is a great honour and pleasure for me to say here a few words about our friend Jean Starobinski as a medical historian. Though his teaching and publishing lays to a larger extent in the field of litterary history, he is, thanks to his incredible fertility, also a medical historian in his own right.

He was through his background and evolution predestined to become one. When he finished his medical studies in 1951 he had already been an assistent in French litterature during three years. He has published in medical history since 1951. His masterful MD thesis of 1960, a «History of the treatment of Melancholy from the beginnings to 1900» reflects his triple origins as a student of medicine (with years of practical experience in hospitals), of litterature, and philosophy. It is full of brilliant observations of therapeutic details (like the psychotherapeutic character of certain writings of Seneca) as well as considerations on general aspects of therapy (like the nature of a panacea versus a specific, or the nature of the black bile notion). Starobinski has repeatedly returned to the melancholy theme, the last time in 1982.

Though his short history of medicine of 1963 demonstrates his familiarity with the whole field, his research has centered mostly around problems of the history of psychopathology and psychotherapy. Here we owe to him several valuable short historical surveys (e.g. on psychosomatic medicine 1954; on passion 1980; on psychology between 1575 and 1625 (1980). Among his numerous studies of isolated problems are such on psychoanalysis, parapsychology, «imaginary fluids» etc. $(1962,1963,1966)$. Most brillant among these seem to me those on Nostalgia $(1961,1962,1963,1966)$ that strange psychosomatic disease, and on Reaction (1975, 1976). In the latter he follows the relatively young notion from its philosophical origins through physics, politics, biology and psychology. The semantic tendencies of our Geneva born author are here particularly visible. (He is not accidentally the editor of Ferdinand de Saussure's Anagrams.)

He has, of course, also discussed authors of particular medicohistorical interest like Descartes $(1953,1959)$. La Rochefoucauld (1955, 1959, 1962 , 1966), who in his way was a «clinician», or Rousseau, one of his main study objects. 
In addition to all these spiritual gifts we Swiss medical historians owe much gratitude to Jean Starobinski for his loyal and disinterested collaboration in our organisation during almost three decades. We are also grateful to him that he, in spite of being extremely popular in the US as a thinker, a person and a musician, has returned to Switzerland. We therefore wish him at his 65 th birthday many happy returns! 